Evaluation of the Water Film Weber Number in Glaze Icing Scaling

Jen-Ching Tsao

Ohio Aerospace Institute, Brook Park, Ohio

Richard E. Kreeger

Glenn Research Center, Cleveland, Ohio

Alejandro Feo

Instituto Nacional de Tecnica Aeroespacial, Madrid, Spain 


\section{NASA STI Program . . . in Profile}

Since its founding, NASA has been dedicated to the advancement of aeronautics and space science. The NASA Scientific and Technical Information (STI) program plays a key part in helping NASA maintain this important role.

The NASA STI Program operates under the auspices of the Agency Chief Information Officer. It collects, organizes, provides for archiving, and disseminates NASA's STI. The NASA STI program provides access to the NASA Aeronautics and Space Database and its public interface, the NASA Technical Reports Server, thus providing one of the largest collections of aeronautical and space science STI in the world. Results are published in both non-NASA channels and by NASA in the NASA STI Report Series, which includes the following report types:

- TECHNICAL PUBLICATION. Reports of completed research or a major significant phase of research that present the results of NASA programs and include extensive data or theoretical analysis. Includes compilations of significant scientific and technical data and information deemed to be of continuing reference value. NASA counterpart of peer-reviewed formal professional papers but has less stringent limitations on manuscript length and extent of graphic presentations.

- TECHNICAL MEMORANDUM. Scientific and technical findings that are preliminary or of specialized interest, e.g., quick release reports, working papers, and bibliographies that contain minimal annotation. Does not contain extensive analysis.

- CONTRACTOR REPORT. Scientific and technical findings by NASA-sponsored contractors and grantees.
- CONFERENCE PUBLICATION. Collected papers from scientific and technical conferences, symposia, seminars, or other meetings sponsored or cosponsored by NASA.

- SPECIAL PUBLICATION. Scientific, technical, or historical information from NASA programs, projects, and missions, often concerned with subjects having substantial public interest.

- TECHNICAL TRANSLATION. Englishlanguage translations of foreign scientific and technical material pertinent to NASA's mission.

Specialized services also include creating custom thesauri, building customized databases, organizing and publishing research results.

For more information about the NASA STI program, see the following:

- Access the NASA STI program home page at http://www.sti.nasa.gov

- E-mail your question via the Internet to help@ sti.nasa.gov

- Fax your question to the NASA STI Help Desk at $443-757-5803$

- Telephone the NASA STI Help Desk at 443-757-5802

- Write to: NASA Center for AeroSpace Information (CASI) 7115 Standard Drive Hanover, MD 21076-1320 


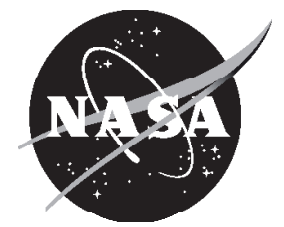

\section{Evaluation of the Water Film Weber Number in Glaze Icing Scaling}

Jen-Ching Tsao

Ohio Aerospace Institute, Brook Park, Ohio

Richard E. Kreeger

Glenn Research Center, Cleveland, Ohio

Alejandro Feo

Instituto Nacional de Tecnica Aeroespacial, Madrid, Spain

Prepared for the

1st Atmospheric and Space Environments Conference

sponsored by the American Institute of Aeronautics and Astronautics

San Antonio, Texas, June 22-25, 2009

National Aeronautics and

Space Administration

Glenn Research Center

Cleveland, Ohio 44135 


\section{Acknowledgments}

The authors wish to thank the NASA Glenn Icing Research Tunnel (IRT) personnel for their excellent and committed technical support.

This report contains preliminary findings, subject to revision as analysis proceeds.

Level of Review: This material has been technically reviewed by technical management.

Available from

NASA Center for Aerospace Information 7115 Standard Drive

Hanover, MD 21076-1320
National Technical Information Service 5301 Shawnee Road Alexandria, VA 22312

Available electronically at http://gltrs.grc.nasa.gov 


\title{
Evaluation of the Water Film Weber Number in Glaze Icing Scaling
}

\author{
Jen-Ching Tsao \\ Ohio Aerospace Institute \\ Brook Park, Ohio 44142 \\ Richard E. Kreeger \\ National Aeronautics and Space Administration \\ Glenn Research Center \\ Cleveland, Ohio 44135 \\ Alejandro Feo \\ Instituto Nacional de Tecnica Aeroespacial \\ Madrid, Spain
}

\begin{abstract}
Icing scaling tests were performed in the NASA Glenn Icing Research Tunnel to evaluate a new scaling method (Ref. 1), developed and proposed by Feo for glaze icing, in which the scale liquid water content and velocity were found by matching reference and scale values of the nondimensional water-film thickness expression and the film Weber number. For comparison purpose, tests were also conducted using the constant $\mathrm{We}_{L}$ method for velocity scaling. The reference tests used a full-span, fiberglass, 91.4-cm-chord NACA 0012 model with velocities of 76 and $100 \mathrm{knot}$ and MVD sizes of 150 and $195 \mu \mathrm{m}$. Scale-to-reference model size ratio was 1:2.6. All tests were made at $0^{\circ} \mathrm{AOA}$. Results will be presented for stagnation point freezing fractions of 0.3 and 0.5 .
\end{abstract}

\section{Introduction}

The ability to conduct icing tests with subscale aircraft components in an icing wind tunnel depends critically on our understanding of physical mechanisms that affect the ice accretion process and our ability to measure and control test conditions in an icing tunnel. The need to develop appropriate scaling methods has been long recognized, and research efforts have begun as early as in the 1950s and continue to the present. Recently, Anderson (Ref. 2) and Anderson and Tsao (Ref. 3) have completed two NASA reports that provide a detailed technical review of recommended scaling methods for ice accretion on unprotected, unswept aerodynamic surfaces in Appendix C and super-cooled large droplets (i.e., SLD) conditions, respectively.

It was concluded from those two references that acceptable scaling results could be achieved by matching the $\beta_{0}, A_{c}, n_{0}$, and $\mathrm{We}_{L}$. With scale model size selected, by matching scale and reference values of $\mathrm{We}_{L}$ the scale velocity can be determined. By matching $\beta_{0}$ the scale $M V D$ can be found. Reference 2 also showed that the effects of temperature and $L W C$ are not independent, but interact through the freezing fraction. Therefore, with scale $L W C$ chosen, by matching $n_{0}$ the scale temperature can be calculated. Finally, by matching $A_{c}$ the scale time can be established. For the scale test, then, only temperature, velocity, $M V D$ and time have to be calculated from the known (reference) values of the similarity parameters.

The results presented here are part of an effort to develop scaling methods for super-cooled large droplets in glaze icing conditions. During glaze-ice accretion water does not freeze immediately in the zone of impingement. The characteristics of the resulting layer of liquid surface water are believed to influence the shape of the accreted ice to some extent and are the subject of a number of ongoing studies. Bilanin (Ref. 4) and Bilanin and Anderson (Ref. 5) advocated adding another similarity parameter, the Weber number, to scaling requirements to address surface-water effects. Two forms of the Weber number 
that might be applied include that based on the droplet $M V D$ and water properties (We) and one based on model size and air properties $\left(\mathrm{We}_{c}\right)$. A third Weber number was suggested by Kind (Ref. 6); this one was based on the thickness of the water film at the leading edge and air properties $\left(\mathrm{We}_{t}\right)$.

Anderson and Ruff (Ref. 7) and Anderson (Ref. 8) reported the best scaling results for glaze ice were achieved when a compromise between constant We and constant Re was used with the modified Ruff method. A possible explanation for this result comes from studies of droplet-surface impact (Ref. 9) for no icing applications. These studies correlated splashing effects with a $K$ factor that depended only on We and $\mathrm{Re}_{\delta}$. Other surface-tension effects such as water-film breakup and rivulet formation are also We and Re dependent.

Finally, in a recent study at above-freezing temperatures, Feo and Urdiales (Ref. 10) measured the water-film thickness, $h$, for heavy-rain conditions. The nondimensional film thickness, $h / d$, was found to correlate with We and $\operatorname{Re}_{\delta}$. The authors suggested that $h / d$ might itself serve as an appropriate similarity parameter for scaling studies. Although spray characteristics for that study were very different from Appendix-C conditions, the heavy-rain $h / d$ was evaluated as a similarity parameter in studies comparing how methods to select scale velocity affected ice shape (Refs. 7 and 8). However, matching the scale and reference $h / d$ of Feo and Urdiales gave scale ice shapes that were generally a poorer match of the reference than did other methods of finding scale velocity. Later, Feo (Ref. 11) measured the thickness of the water film for $M V D$ and $L W C$ conditions near those in an icing cloud and correlated the results with $L W C$ and Re. In the study he suggested another Weber number based on the water film thickness and water properties $\left(\mathrm{We}_{h}\right)$ as a similarity parameter for scaling studies. Evaluations of the constant-waterfilm-thickness and constant-Weber-number methods in scaling tests using this new $h / d$ correlation have been made (Ref. 12) and the results compared reasonably well with those using the Weber number We.

In another more recent study (Ref. 1), similarity parameters involved in surface water film dynamics were proposed. The film Weber Number ( $\mathrm{We}_{f}$ ) that was defined before (Ref. 13) was introduced with the nondimensional film thickness, being both required to be matched at scale and reference conditions. The parametric $(h / d)$ expressions were obtained from two sets of experiments that were conducted in one of INTA'S Low Speed Tunnels; one being for Appendix C (Refs. 11 and 14) and the other for SLD droplets (Ref. 15). In addition, Feo has also suggested a slightly different approach from the modified Ruff method as recommended in References 2 and 3 to determine appropriate scale test conditions. Three of the five similarity expressions used were from well-established methods (droplets' trajectories, freezing fraction and ice accumulation) and the other two requirements were obtained by using $\mathrm{We}_{f}=$ const. and $(h / d)=$ const., the last one being taken from experiments. Depending on the expression of $(h / d)$ used; we have results either for Appendix C or SLD droplets. However there was no exact icing test results available at the time to properly evaluate the proposed scaling method and the need of more experimental work related to this specific method was recommended in Reference 1.

This evaluation was a goal of the present study, along with the evaluation of the constant $\mathrm{We}_{L}$ method in glaze icing conditions with SLD reference droplet sizes in the range of 100 to $200 \mu \mathrm{m}$.

\section{Nomenclature}

$A_{c} \quad$ Accumulation parameter, dimensionless

$b \quad$ Relative heat factor, dimensionless

$c \quad$ Airfoil chord, $\mathrm{cm}$

$d \quad$ Cylinder radius or twice the leading-edge radius of airfoil, $\mathrm{cm}$

$h \quad$ Water film thickness, $\mathrm{cm}$

$K_{0} \quad$ Modified inertia parameter, dimensionless

$L W C$ Cloud liquid-water content, $\mathrm{g} / \mathrm{m}^{3}$

$M V D$ Water droplet median volume diameter, $\mu \mathrm{m}$

$n \quad$ Local freezing fraction, dimensionless

$n_{0} \quad$ Stagnation point freezing fraction, dimensionless

Re Reynolds number of model, dimensionless 
$\mathrm{Re}_{\delta} \quad$ Reynolds number of water drop, dimensionless

$t_{s t} \quad$ Static temperature, ${ }^{\circ} \mathrm{C}$

$V \quad$ Air velocity, kt

We Weber number based on droplet size and water properties, dimensionless

$\mathrm{We}_{c}$ Weber number based on model size and air properties, dimensionless

$\mathrm{We}_{h}$ Weber number based on water-film thickness, air velocity and water properties, dimensionless

$\mathrm{We}_{f}$ Weber number based on water-film thickness, water properties and film velocity, dimensionless

$\mathrm{We}_{L}$ Weber number based on model size and water properties, dimensionless

$\mathrm{We}_{t} \quad$ Weber number based on water-film thickness and air velocity and properties, dimensionless

$\mathrm{We}_{\delta} \quad$ Weber number based on droplet size and air properties, dimensionless

$\beta_{0} \quad$ Collection efficiency at stagnation line, dimensionless

$\phi \quad$ Droplet energy transfer parameter, ${ }^{\circ} \mathrm{C}$

$\tau \quad$ Accretion time, min

\section{Subscripts}

$R$ reference

$S$ scale

$f$ water film

st static

tot total

\section{Similarity Parameters}

The similarity parameters used in this study were based on the work originally done by Ruff (Ref. 16). The current scaling method (i.e., the modified Ruff method) required matching scale and reference values of the key similarity parameters, $\beta_{0}, A_{c}, n_{0}$, and $\mathrm{We}_{L}$ with scale $L W C$ chosen at user's convenience. In Feo's approach, matching reference and scale film Weber number $\mathrm{We}_{f}$ set the scale velocity, and matching nondimensional film thickness parameter $h / d$ set the scale $L W C$. The equations for the similarity parameters will be presented here without much discussion. Therefore, readers who are interested in the physical descriptions and detailed derivations of these parameters are referred to References 1 to 3 and the references given therein.

To maintain the droplet trajectory similitude, Langmuir and Blodgett (Ref. 17) introduced the modified inertia parameter, $K_{0}$, defined as

$$
K_{0}=\frac{1}{8}+\frac{\lambda}{\lambda_{\text {Stokes }}}\left(K-\frac{1}{8}\right)
$$

In Equation (1), $K$ is the inertia parameter,

$$
K=\frac{\rho_{w} M V D^{2} V}{18 d \mu}
$$

Departing slightly from Langmuir and Blodgett in this study, $d$ is twice the leading-edge radius of curvature for airfoils. For the NACA 0012 airfoil model, a leading-edge radius of $0.0158 c$ was used (see Abbott and von Doenhoff (Ref. 18)), where $c$ is the airfoil chord. $\lambda / \lambda_{\text {Stokes }}$ is the droplet range parameter, defined as the ratio of actual droplet range to that if Stokes drag law for solid-spheres applied. It is a function only of the droplet Reynolds number, $\mathrm{Re}_{\delta}$.

$$
\operatorname{Re}_{\delta}=\frac{V M V D \rho}{\mu}
$$


This study used a curve fit to Langmuir and Blodgett's tabulation of the range parameter as given in the following expression:

$$
\frac{\lambda}{\lambda \text { Stokes }}=\frac{1}{\left(0.8388+0.001483 \mathrm{Re}_{\delta}+0.1847 \sqrt{\mathrm{Re}_{\delta}}\right)}
$$

Of more practical interest than $K_{0}$ is the collection efficiency at the stagnation point, $\beta_{0}$, which was shown by Langmuir and Blodgett to be a function only of $K_{0}$,

$$
\beta_{0}=\frac{1.40\left(K_{0}-\frac{1}{8}\right)^{.84}}{1+1.40\left(K_{0}-\frac{1}{8}\right)^{.84}}
$$

Thus the droplet trajectory similarity is satisfied if $K_{0, S}=K_{0, R}$ (so does $\beta_{0, S}=\beta_{0, R}$ ), and the scale drop size, i.e., scale $M V D$, is determined. To ensure water-catch similarity, the accumulation parameter is introduced:

$$
A_{c}=\frac{L W C V \tau}{d \rho_{i}}
$$

If all the water impinging on the leading edge freezes at that location and the leading-edge collection efficiency is 100 percent, $A_{c}$ directly becomes a measure of the normalized thickness of ice that will accrete. The scale accretion time can be found from $A_{c, S}=A_{c, R}$. However if it is not possible to find scaled conditions that permit a match of $K_{0}$ (and therefore $\beta_{0}$ ) and $A_{c}$ separately, it is recommended that the product of $\beta_{0} A_{c}$ be matched provided the two collection efficiencies, $\beta_{0, S}$ and $\beta_{0, R}$, be within 10 percent, see Reference 2 for details.

The rate at which the water freezes on a surface depends on the magnitude of local heat transfer imbalance. For glaze ice, it is known that the fraction of water that freezes is less than unity, and the motion of unfrozen surface water can have an effect on the resulting ice shape. Therefore, it is important to maintain surface energy and surface-water dynamics similarities for glaze ice accretions. The freezing fraction is formally defined as the ratio of the amount of water that freezes at a given surface location to the total amount of water that impinges at that location. From Messinger's (Ref. 19) steady-state surface energy balance analysis, the stagnation point freezing fraction can be written as

$$
n_{0}=\frac{c_{p, w s}}{\Lambda_{f}}\left(\phi+\frac{\theta}{b}\right)
$$

The key terms in this formulation include $\phi$ and $\theta$, which have dimensions of temperature and relate to the water drop energy transfer and air energy transfer, and $b$, the relative heat factor, which was first introduced by Tribus, et al. (Ref. 20)

$$
\varphi=t_{f}-t_{s t}-\frac{V^{2}}{2 c_{p, w s}}
$$




$$
\begin{gathered}
\theta=\left(t_{s}-t_{s t}-r \frac{V^{2}}{2 c_{p}}\right)+\frac{h_{G}}{h_{c}}\left(\frac{\frac{p_{w w}}{T_{s t}}-\frac{p_{t o t}}{T_{t o t}} \frac{p_{w}}{p_{s t}}}{\frac{1}{622} \frac{p_{t o t}}{T_{t o t}}-\frac{p_{w w}}{T_{s t}}}\right) \Lambda_{v} \\
b=\frac{L W C V \beta_{0} c_{p, w s}}{h_{c}}
\end{gathered}
$$

Equation (9) from Ruff (Ref. 16) has included compressibility effects. Various incompressible forms of $\theta$ have also been used by Charpin and Fasso (Ref. 21) and others; however, the differences are not significant mainly due to the fact that, for most icing conditions, the Mach number is relatively low. Since only limited combinations of $M V D$ s and $L W C$ s in the SLD regime are currently available in the IRT, the stagnation point freezing fraction is matched to find the scale static temperature instead of the scale $L W C$ value in this study.

Because the original Ruff method does not restrict the value of scale velocity, an additional similarity parameter can be used to determine $V_{S}$. In 2003 Anderson and Tsao (Ref. 22) had provided experimental evidence from past studies to show that a similarity parameter dependent on the ratio $V^{x} c^{y} / \sigma^{z}$ must be included in scaling methodology to account for surface-water dynamics effect in glaze ice accretions, although the powers $x, y$, and $z$ are not yet determined. The length may not be chord itself but rather some physical characteristic $L$ related to chord; for example, the water-film thickness. Likewise, the velocity could also be of the water-film which is related to $V$. Thus a Weber number based on $L$ and $V$

$$
\mathrm{We}_{L}=\frac{V^{2} L \rho_{w}}{\sigma}
$$

has been suggested as a potential additional similarity parameter to supplement Ruff's basic scaling method. Studies by Bartlett (Refs. 23 and 24) and Oleskiw, et al., (Ref. 25) found no measurable effect of pressure on ice shape. These observations suggest that water density is a better choice than air density for Equation (11). In this study the $\mathrm{We}_{L}$ is based on the twice the nose radius of the airfoil:

$$
\mathrm{We}_{L}=\frac{V^{2} d \rho_{w}}{\sigma}
$$

with the understanding that $L \propto d$. The scale velocity found from matching $\mathrm{We}_{L, S}=\mathrm{We}_{L, R}$ is

$$
V_{S}=V_{R}\left(\frac{d_{R}}{d_{S}}\right)^{1 / 2}
$$

Another approach presented by Feo (Ref. 13) involved matching simultaneously the water-film thickness and a Weber number that used the water-film velocity and water-film thickness:

$$
\mathrm{We}_{f}=\frac{V_{f}^{2} h_{f} \rho_{w}}{\sigma}
$$

By equating shear stresses at the air-water interface, the water-film velocity can be written as 


$$
V_{f}=\operatorname{Re}^{1 / 2}\left(\frac{h_{f}}{d}\right) V
$$

When Equation (15) is substituted into Equation (14) and letting scale and reference values of $\left(h_{f} / d\right)$ be equated while matching $\mathrm{We}_{f, S}=\mathrm{We}_{f, R}$, the expression becomes

$$
\left(\operatorname{ReWe}_{L}\right)_{S}=\left(\operatorname{ReWe}_{L}\right)_{R}
$$

From Equation (16) the scale velocity for this Feo method is

$$
V_{S}=V_{R}\left(\frac{d_{R}}{d_{S}}\right)^{2 / 3}
$$

The Reynolds number Re shown above is also based on the twice the nose radius of the airfoil:

$$
\operatorname{Re}=\frac{V d \rho}{\mu}
$$

For large SLD drop sizes where droplet impact could strongly interact with the surface air-driven film flow, the best correlation of the experimental film thickness data (Ref. 15) was found to be

$$
h / d \propto\left(\frac{L W C}{\rho_{w}}\right)^{1 / 2} \operatorname{Re}^{-1 / 4} \mathrm{We}_{c}^{-1 / 2}\left(\mathrm{We}_{\delta}^{1 / 2} \mathrm{Re}_{\delta}^{-1}\right)
$$

By matching scale and reference values of nondimensional film thickness $(h / d)$, a scale $L W C$ was determined

$$
L W C_{S}=L W C_{R}\left(\frac{d_{R}}{d_{S}}\right)^{-0.7}
$$

\section{Test Description}

\section{Facility, Model, and Procedures}

The scaling tests were performed in the NASA Glenn Icing Research Tunnel (IRT). The IRT is a closed-loop, refrigerated, sea level tunnel with a 1.8 by $2.7 \mathrm{~m}$ rectangular test section. The icing cloud is generated by operating 10 spray bars, a configuration in use since 1998.

The IRT cloud calibrations for both Appendix-C and SLD conditions used for these tests were performed in the summer of 2008. The $L W C$ measurements were made using icing blade method as reported previously (Ref. 26). However, during the 2008 calibration there was not enough time to perform $M V D$ measurements. The $M V D$ s reported in this paper are based on an analysis of the $M V D$ calibration data completed in February 2006. In addition, because only a few specific $M V D-L W C$ combinations at speeds of 100, 150, 200, and $250 \mathrm{kt}$ (i.e., 51, 77, 103, and $128 \mathrm{~m} / \mathrm{s}$ ) have been calibrated to date in the SLD regime, additional $L W C$ measurements for SLD conditions were made in the IRT on September 22, 2008, with an icing blade. Therefore SLD tests are constrained to these particular conditions. 
The models used were NACA 0012 airfoil sections with chords of 91.4 and $35.6 \mathrm{~cm}$. The $91.4-\mathrm{cm}-$ chord airfoil is pictured in Figure 1(a). It was a full-span, fiberglass model at $0^{\circ}$ angle of attack and served as the reference model. The $35.6-\mathrm{cm}$-chord scale model was of $61-\mathrm{cm}$ span and made of aluminum. It was mounted vertically between splitter plates at the center of the IRT test section as shown in Figure 1(b). Horizontal lines at the leading edge were drawn at the tunnel vertical center (model mid span) and $\pm 2.5 \mathrm{~cm}$ from the center to locate ice-tracing templates. Vertical lines were also placed at increments of $2.5 \mathrm{~cm}$ (labeled in inches on the model), measured along the surface from the stagnation line. These marks helped to identify sites on the model for close-up photographs of feather structure details. Because of the quick-start capability of the IRT spray system, no shielding of the models was required during the initiation of the spray.

In preparing for a test, the temperature and airspeed in the test section and the air and water pressures on the spray manifolds were set. When these conditions had stabilized, the spray nozzle valves were opened to initiate the spray. The spray was timed for the required duration, and then turned off. The fan was brought to a full stop and the researchers entered the test section to document the ice shape with hand tracings. Close-up photographs were also taken with a hand-held digital camera.

To record the ice shapes, a thin slice was first melted through the ice normal to the model surface. A cardboard template was then placed into this slit and an outline of the ice shape traced by pencil, giving a two-dimensional cross section of the ice. Tracings were taken at the vertical center of the tunnel $(91 \mathrm{~cm}$ from the floor) and at $2.5 \mathrm{~cm}$ above the center. The ice shapes so recorded were digitized using an automated line-following feature in the image-analysis software, SigmaScan Pro (Ref. 27). The results presented in this study are from IRT test entry in September 2008. Since the shape differences between the two tracing locations were never significant, only centerline shapes will be reported here.

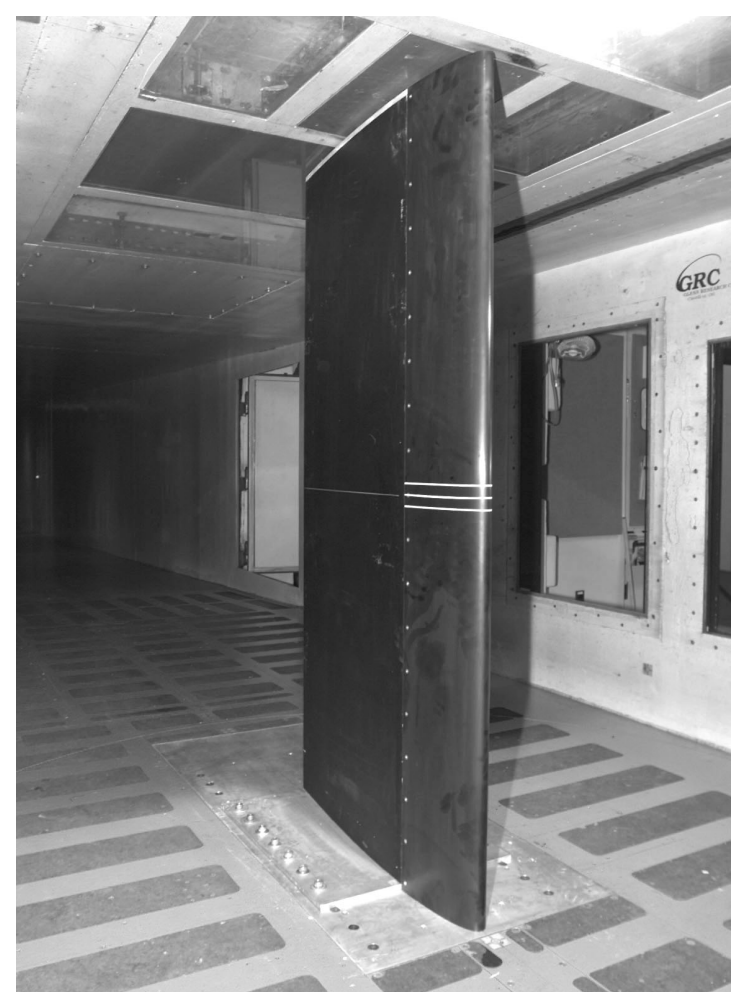

(a) 91.4-cm-Chord NACA 0012 Model

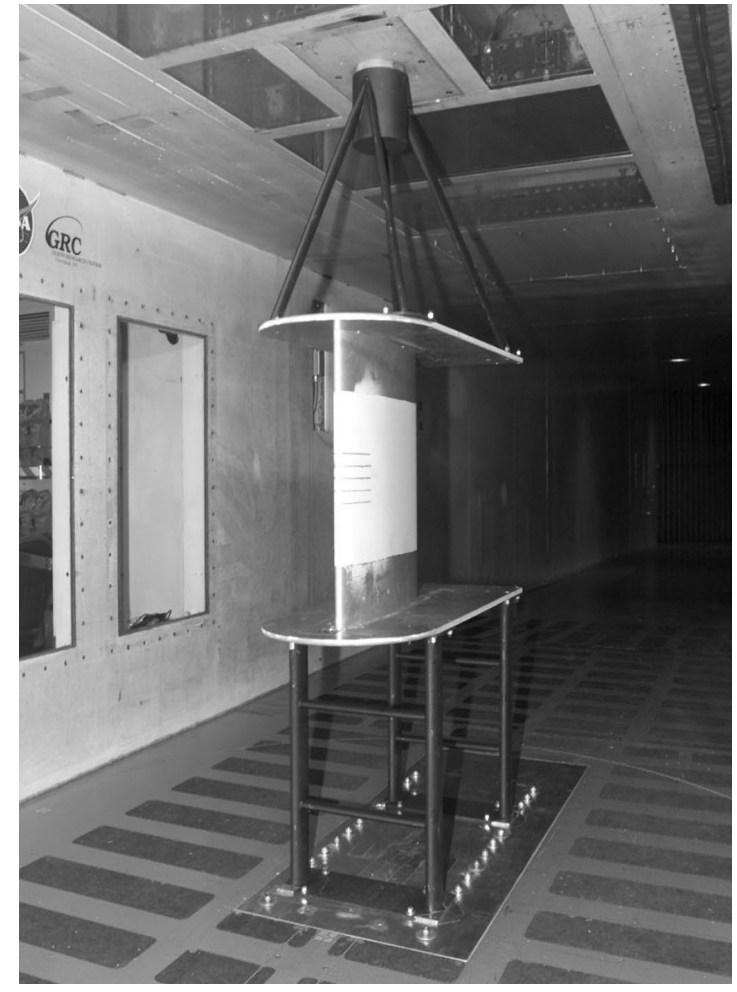

(b) 35.6-cm-Chord NACA 0012 Model

Figure 1.-Models installed in IRT test section. 


\section{Uncertainty Analysis}

Estimates of the uncertainty in the reported average conditions were made by considering inherent errors of instruments, temporal fluctuation and spatial variation of the instrument readings in the test section, and uncertainty in tunnel calibration of $M V D$ and $L W C$. Recorded air temperature was believed to be accurate to $\pm 0.2^{\circ} \mathrm{C}$, although variations during the period of an icing spray increases the uncertainty for reported average temperatures to about $\pm 0.5^{\circ} \mathrm{C}$. The uncertainty in air velocity was estimated to be \pm 2 kt. For Appendix-C conditions the net uncertainty in $M V D$ was estimated at \pm 12 percent. For SLD conditions it may have been as much as \pm 20 percent. These uncertainties are not referenced to an absolute value of $M V D$, which is unknown. Repeatability and scatter in the $L W C$ calibration data suggests the uncertainty is about \pm 12 percent for both Appendix-C and SLD conditions.

The test-parameter uncertainties were used to estimate the following uncertainties in the similarity parameters for the SLD tests the uncertainties were: 2 percent in $\beta_{0}, 12$ percent in $A_{c}, 10$ percent in $n_{0}$, 2 percent in $\mathrm{Re}, 3$ percent in $\mathrm{We}_{L}$, and 5 percent in $\mathrm{We}_{f}$.

\section{Results}

In planning the test matrix, reference test conditions were chosen so that both reference and scale conditions would fall within the IRT operating envelope. Due to very limited IRT test time available for the scaling evaluation this study is only focused on the SLD droplets. Also, since only limited combinations of $M V D$ s and $L W C$ s in the SLD regime are currently available in the IRT, it was decided early on for time-saving purpose that the scale $L W C$ values obtained from Equation (20), as recommended by Feo to ensure constant $h / d$, would also be used for the evaluation of the constant $\mathrm{We}_{L}$ method.

Figures 2 to 9 present the nondimensional reference and scale ice shapes recorded using two methods for finding scale velocity: the constant $\mathrm{We}_{L}$ and constant $\mathrm{We}_{f}$ for stagnation point freezing fraction of 0.3 and 0.5 at reference velocities of 76 and $100 \mathrm{kt}$. For each figure, reference ice shape was shown shaded, while a solid line indicated the scale shape. The table below each figure gave the test conditions and similarity parameters for each pair of reference and scale tests. The conditions given were the average conditions recorded over the duration of each test, which can sometimes differ slightly from the planned set points. The parameters in the tables were calculated from these average conditions.

\section{Stagnation Point Freezing Fraction of 0.3}

Figures 2 and 3 show reference and scale ice shape comparisons for the constant $\mathrm{We}_{L}$ and constant $\mathrm{We}_{f}$ methods, respectively. The same reference ice shape was used for both comparisons. The reference model size, velocity and $M V D$ were $91.4 \mathrm{~cm}, 76 \mathrm{kt}$, and $150 \mu \mathrm{m}$. The scale model size was $35.6 \mathrm{~cm}$. The coordinates of the ice shapes were all normalized by the corresponding model chord.

In Figure 2 the scale and reference values of $\beta_{0}, n_{0}$, and $\mathrm{We}_{L}$ matched within 3 percent and $A_{c}$ was just within 9 percent. This was because the reference $L W C$ value was reduced to 87 percent of the planned value (i.e., 1.68 instead of $1.93 \mathrm{~g} / \mathrm{m}^{3}$ ) and the scale $L W C$ was reduced by 5 percent from its planned value (i.e., 0.95 instead of $1.00 \mathrm{~g} / \mathrm{m}^{3}$ ) based on the calibration performed in the IRT on September 22, 2008. The scale ice shape however closely simulated the reference main ice shape and feather region, even including smaller feathers further aft on the surface.

In Figure 3 the scale and reference values of $\beta_{0}$ matched well but $A_{c}$ and $\beta_{0} A_{c}$ were just within 16 percent, $n_{0}$ was within 10 percent, $\mathrm{We}_{f}$ agreed only within about 37 percent and $h / d$ was within 15 percent. Such large disagreement of $\mathrm{We}_{f}$ and $h / d$ occurred mainly because, in addition to the decrease in the reference $L W C$ value mentioned previously, now the scale $L W C$ value was further increased to 117 percent of the planned value (i.e., 1.17 instead of $1.00 \mathrm{~g} / \mathrm{m}^{3}$ ) based on the calibration data. The Olsen method was used in this case to adjust the spray time and air total temperature for scale test due to the $L W C$ value change from the calibration such that $n_{0}$ and $\beta_{0} A_{c}$ would stay close to the planned value. As a result, the size and shape of the reference ice were simulated fairly well by the scale test in the leading-edge region, though missing the horn angle in the upper feather region. 


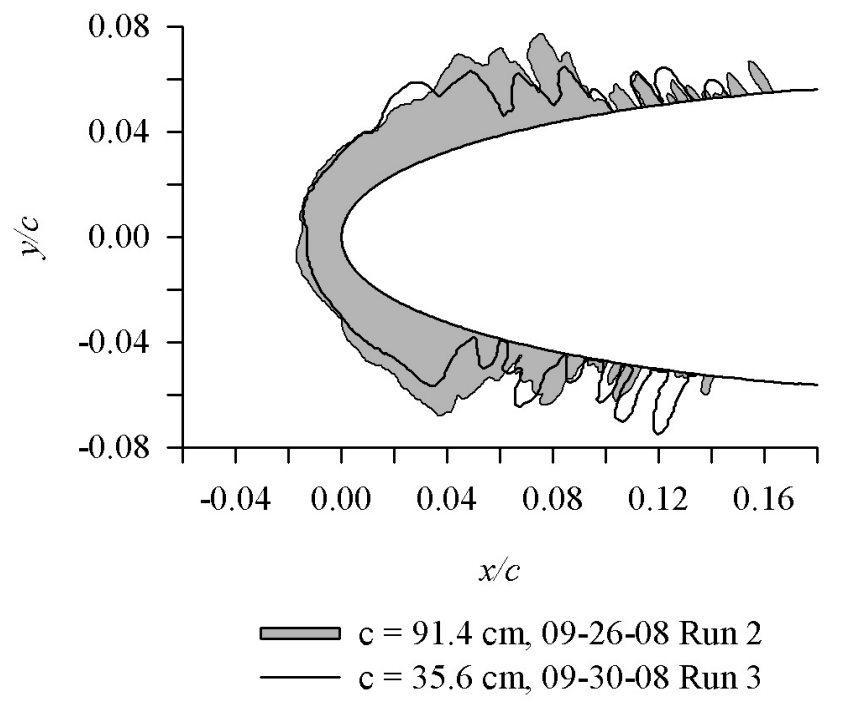

\begin{tabular}{cccccccccccccc} 
Date/Run & $\begin{array}{c}c, \\
\mathrm{~cm}\end{array}$ & $\begin{array}{c}t_{\text {tot }}, \\
{ }^{\circ} \mathrm{C}\end{array}$ & $\begin{array}{c}V, \\
\mathrm{kt}\end{array}$ & $\begin{array}{c}M V D, \\
\mu \mathrm{m}\end{array}$ & $\begin{array}{c}L W C, \\
\mathrm{~g} / \mathrm{m}^{3}\end{array}$ & $\begin{array}{c}\tau, \\
\min \end{array}$ & $\begin{array}{c}\beta_{0}, \\
\text { percent }\end{array}$ & $A_{c}$ & $\beta_{0} A_{c}$ & $n_{0}$ & $\begin{array}{c}\mathrm{We}_{L}, \\
10^{6}\end{array}$ & $\begin{array}{c}\mathrm{We}_{f}, \\
10^{-16}\end{array}$ & $\begin{array}{c}h / d, \\
10^{-9}\end{array}$ \\
\hline $09-26-08 / 02$ & 91.4 & -10.2 & 76 & 147 & 1.68 & 11.02 & 94.1 & 1.66 & 1.56 & 0.32 & 0.67 & 2.80 & 1.68 \\
$09-30-08 / 03$ & 35.6 & -4.9 & 120 & 68 & 0.95 & 5.26 & 94.2 & 1.80 & 1.69 & 0.31 & 0.66 & 3.33 & 2.13
\end{tabular}

Figure 2.-Scaling from 91.4 to $35.6-\mathrm{cm}$-chord with $\mathrm{We}_{L}$ matched. NACA 0012 airfoils; $n_{0}, 0.3 ; V_{R}, 76 \mathrm{kt}$.

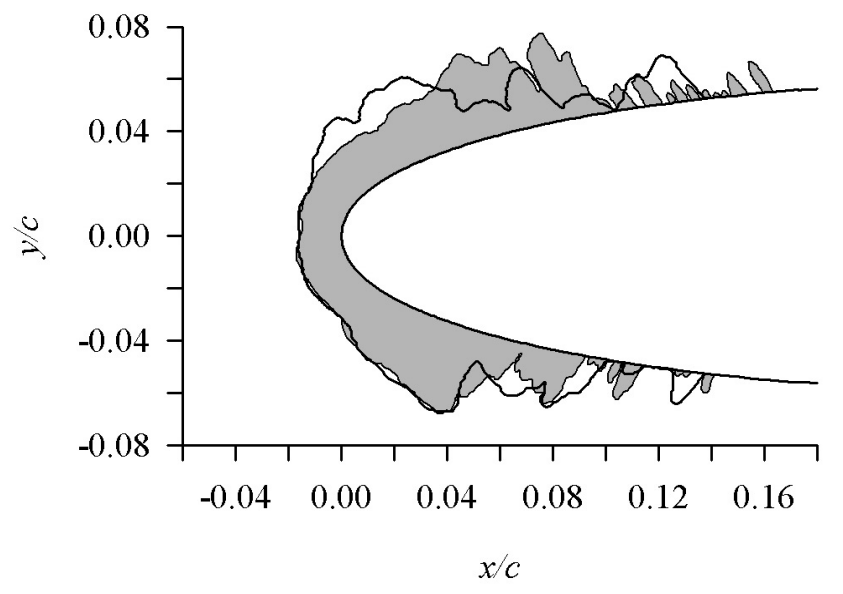

ए $=91.4 \mathrm{~cm}, 09-26-08$ Run 2

$\mathrm{c}=35.6 \mathrm{~cm}, 09-30-08$ Run 4

\begin{tabular}{cccccccccccccc} 
Date/Run & $\begin{array}{c}c, \\
\mathrm{~cm}\end{array}$ & $\begin{array}{c}t_{\text {tot }}, \\
{ }^{\circ} \mathrm{C}\end{array}$ & $\begin{array}{c}V, \\
\mathrm{kt}\end{array}$ & $\begin{array}{c}M V D, \\
\mu \mathrm{m}\end{array}$ & $\begin{array}{c}L W C, \\
\mathrm{~g} / \mathrm{m}^{3}\end{array}$ & $\begin{array}{c}\tau, \\
\mathrm{min}\end{array}$ & $\begin{array}{c}\beta_{0}, \\
\text { percent }\end{array}$ & $A_{c}$ & $\beta_{0} A_{c}$ & $n_{0}$ & $\begin{array}{c}\mathrm{We}_{L}, \\
10^{6}\end{array}$ & $\begin{array}{c}\mathrm{We}_{f,} \\
10^{-16}\end{array}$ & $\begin{array}{c}h / d, \\
10^{-9}\end{array}$ \\
\hline $09-26-08 / 02$ & 91.4 & -10.2 & 76 & 147 & 1.68 & 11.2 & 94.1 & 1.66 & 1.56 & 0.32 & 0.67 & 2.80 & 1.68 \\
$09-30-08 / 04$ & 35.6 & -5.5 & 142 & 66 & 1.17 & 4.00 & 94.3 & 1.98 & 1.87 & 0.29 & 0.92 & 4.26 & 1.97
\end{tabular}

Figure 3.-Scaling from 91.4 to $35.6-\mathrm{cm}$-chord with $\mathrm{We}_{f}$ and $(h / d)$ matched. NACA 0012 airfoils; $n_{0}, 0.3 ; V_{R}, 76 \mathrm{kt}$. 
In addition, Figures 4 and 5 gave SLD scaling results for a higher reference velocity of 100 kt with the 91.4-cm-chord 195- $\mu \mathrm{m}-M V D$ reference conditions scaled to $35.6 \mathrm{~cm}$. In both cases, the scale and reference values of $\beta_{0}, \beta_{0} A_{c}$ and $n_{0}$ matched within 3 percent. The reference and scale $\mathrm{We}_{L}$ in Figure 4 matched well and the $\mathrm{We}_{f}$ and $h / d$ in Figure 5 agreed within about 3 percent. The 35.6-cm-chord scale tests produced main ice shapes in fairly good agreement with the reference though the constant $\mathrm{We}_{L}$ method did seem to simulate the leading-edge region better. Even the sizes of large feathers adjacent to the main shape and the smaller feathers further aft were simulated reasonably well (except for a few larger feathers further aft on the lower surface in both figures).

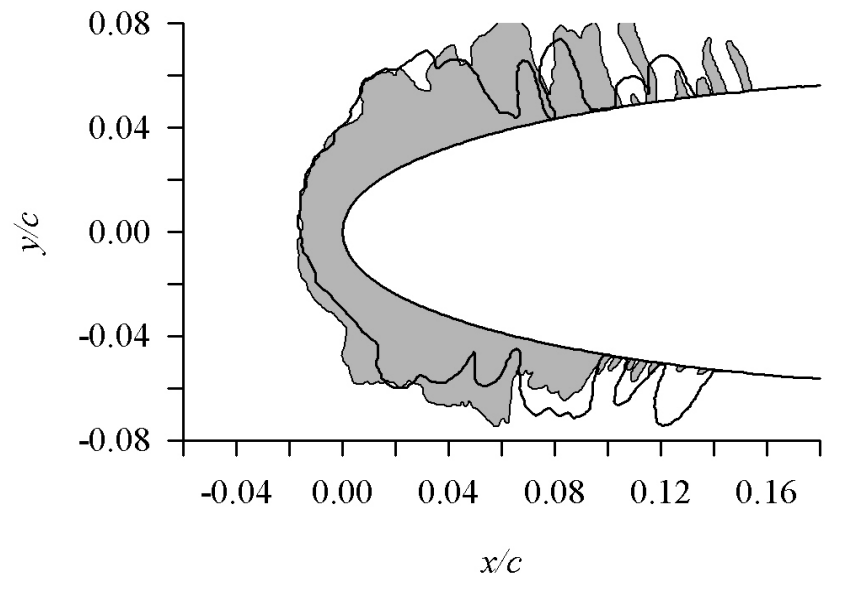

\begin{tabular}{|c|c|c|c|c|c|c|c|c|c|c|c|c|c|}
\hline \multirow[b]{2}{*}{ Date/Run } & \multirow[b]{2}{*}{$\begin{array}{c}c, \\
\mathrm{~cm}\end{array}$} & \multirow[b]{2}{*}{${ }_{t o t}^{t_{t o t}}$} & \multirow[b]{2}{*}{$\begin{array}{l}V, \\
\mathrm{kt}\end{array}$} & \multirow[b]{2}{*}{$\begin{array}{c}M V D, \\
\mu \mathrm{m}\end{array}$} & \multicolumn{5}{|c|}{$\Longrightarrow \mathrm{c}=91.4 \mathrm{~cm}, 09-26-08$ Run 1} & \multirow[b]{2}{*}{$n_{0}$} & \multirow[b]{2}{*}{$\begin{array}{c}\mathrm{We}_{L}, \\
10^{6}\end{array}$} & \multirow[b]{2}{*}{$\begin{array}{l}\mathrm{We}_{f} \\
10^{-16}\end{array}$} & \multirow[b]{2}{*}{$\begin{array}{l}h / d, \\
10^{-9}\end{array}$} \\
\hline & & & & & $\begin{array}{l}L W C, \\
\mathrm{~g} / \mathrm{m}^{3}\end{array}$ & $\underset{\min }{\tau}$ & $\begin{array}{c}\beta_{0}, \\
\text { percent }\end{array}$ & $A_{c}$ & $\beta_{0} A_{c}$ & & & & \\
\hline $09-26-08 / 01$ & 91.4 & -7.8 & 100 & 198 & 1.08 & 14.0 & 96.3 & 1.75 & 1.69 & 0.31 & 1.17 & 0.74 & 0.82 \\
\hline $09-30-08 / 02$ & 35.6 & -2.9 & 159 & 87 & 0.57 & 6.62 & 96.2 & 1.80 & 1.73 & 0.31 & 1.16 & 0.86 & 1.04 \\
\hline
\end{tabular}

Figure 4.-Scaling from 91.4 to $35.6-\mathrm{cm}$-chord with $\mathrm{We}_{L}$ matched. NACA 0012 airfoils; $n_{0}, 0.3 ; V_{R}, 100 \mathrm{kt}$.

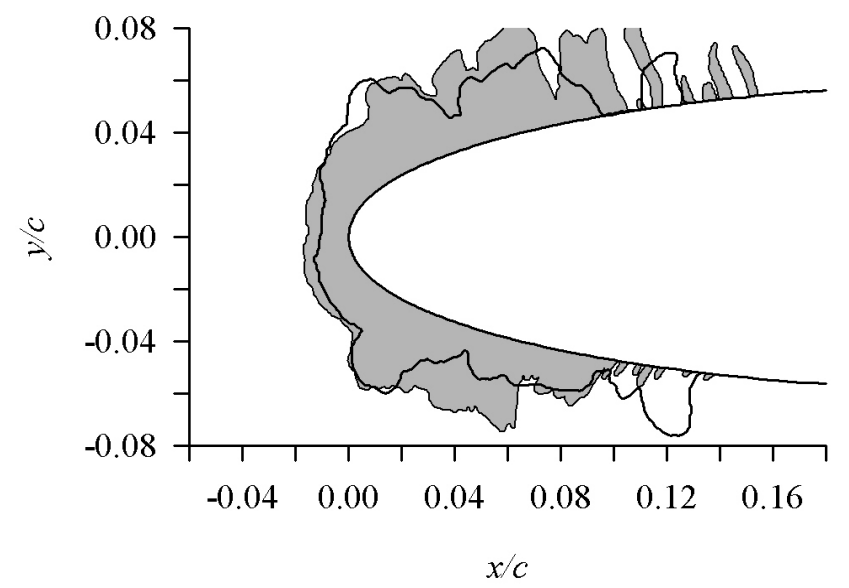

\begin{tabular}{|c|c|c|c|c|c|c|c|c|c|c|c|c|c|}
\hline \multirow[b]{2}{*}{ Date/Run } & \multirow[b]{2}{*}{$\begin{array}{l}c, \\
\mathrm{~cm}\end{array}$} & \multirow[b]{2}{*}{$\begin{array}{c}t_{\text {tot }}, \\
{ }^{\circ} \mathrm{C}\end{array}$} & \multirow[b]{2}{*}{$\begin{array}{l}V, \\
\mathrm{kt}\end{array}$} & \multirow[b]{2}{*}{$\begin{array}{c}M V D, \\
\mu \mathrm{m}\end{array}$} & \multicolumn{5}{|c|}{$\begin{aligned} \mathrm{c} & =91.4 \mathrm{~cm}, 09-26-08 \text { Run } 1 \\
\mathrm{c} & =35.6 \mathrm{~cm}, 09-30-08 \text { Run } 1\end{aligned}$} & \multirow[b]{2}{*}{$n_{0}$} & \multirow[b]{2}{*}{$\begin{array}{c}\mathrm{We}_{L}, \\
10^{6}\end{array}$} & \multirow[b]{2}{*}{$\begin{array}{l}\mathrm{We}_{f}, \\
10^{-16}\end{array}$} & \multirow[b]{2}{*}{$\begin{array}{l}h / d, \\
10^{-9}\end{array}$} \\
\hline & & & & & $\begin{array}{l}L W C, \\
\mathrm{~g} / \mathrm{m}^{3}\end{array}$ & $\begin{array}{c}c=3 \\
\tau, \\
\min \end{array}$ & $\begin{array}{c}6 \mathrm{~cm}, 0 \\
\beta_{0}, \\
\text { percent }\end{array}$ & $\begin{aligned}-30-0 \\
A_{c}\end{aligned}$ & $\begin{array}{l}\text { Run } 1 \\
\beta_{0} A_{c}\end{array}$ & & & & \\
\hline $26-08 / 01$ & 91.4 & -7.8 & 100 & 198 & 1.08 & 14.0 & 96.3 & 1.75 & 1.69 & 0.31 & 1.17 & 0.74 & 0.82 \\
\hline $09-30-08 / 01$ & 35.6 & -2.7 & 185 & 86 & 0.54 & 5.65 & 96.4 & 1.69 & 1.63 & 0.32 & 1.56 & 0.72 & 0.84 \\
\hline
\end{tabular}

Figure 5.-Scaling from 91.4 to $35.6-\mathrm{cm}$-chord with $\mathrm{We}_{f}$ and $(h / d)$ matched. NACA 0012 airfoils; $n_{0}, 0.3 ; V_{R}, 100 \mathrm{kt}$. 


\section{Stagnation Point Freezing Fraction of 0.5}

Figures 6 and 7 each compare reference and scale ice shapes with the 91.4-cm reference conditions scaled to $35.6 \mathrm{~cm}$. The same reference ice shape was used for both comparisons. The reference velocity and $M V D$ were $76 \mathrm{kt}$ and $150 \mu \mathrm{m}$. In Figure 6 the scale velocity was calculated from Equation (13), whereas that for Figure 7 was obtained from Equation (17).

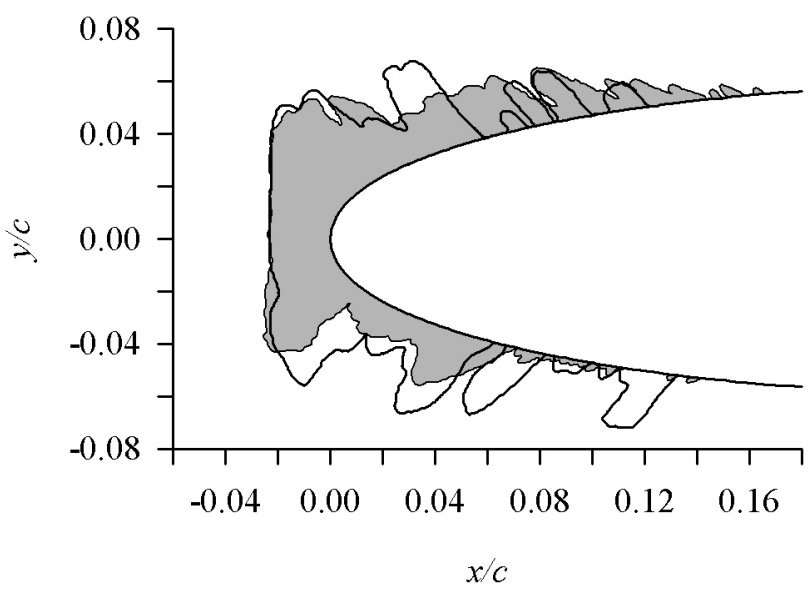

\begin{tabular}{|c|c|c|c|c|c|c|c|c|c|c|c|c|c|}
\hline \multirow[b]{2}{*}{ Date/Run } & \multirow[b]{2}{*}{$\begin{array}{c}c, \\
\mathrm{~cm}\end{array}$} & \multirow[b]{2}{*}{$\begin{array}{c}t_{t o t} \\
{ }^{\circ} \mathrm{C}\end{array}$} & \multirow[b]{2}{*}{$\begin{array}{l}V, \\
\mathrm{kt}\end{array}$} & \multirow[b]{2}{*}{$\begin{array}{c}M V D, \\
\mu \mathrm{m}\end{array}$} & \multicolumn{5}{|c|}{$\mathrm{c}^{2}=91.4 \mathrm{~cm}, 09-26-08$ Run 4} & \multirow[b]{2}{*}{$n_{0}$} & \multirow[b]{2}{*}{$\begin{array}{c}\mathrm{We}_{L}, \\
10^{6}\end{array}$} & \multirow[b]{2}{*}{$\begin{array}{l}\mathrm{We}_{f} \\
10^{-16}\end{array}$} & \multirow[b]{2}{*}{$\begin{array}{l}h / d, \\
10^{-9}\end{array}$} \\
\hline & & & & & $\begin{array}{c}L W C, \\
\mathrm{~g} / \mathrm{m}^{3}\end{array}$ & $\begin{array}{c}\mathrm{c}= \\
\tau, \\
\min \end{array}$ & $\begin{array}{c}5.6 \mathrm{~cm}, \\
\beta_{0}, \\
\text { percent }\end{array}$ & $\begin{array}{c}9-30- \\
A_{c}\end{array}$ & $\begin{array}{l}\operatorname{Run} 8 \\
\beta_{0} A_{c}\end{array}$ & & & & \\
\hline $09-26-08 / 04$ & 91.4 & -18.1 & 76 & 148 & 1.78 & 11.2 & 94.1 & 1.76 & 1.66 & 0.52 & 0.68 & 3.03 & 1.68 \\
\hline $09-30-08 / 08$ & 35.6 & -9.0 & 121 & 68 & 0.94 & 5.26 & 94.2 & 1.79 & 1.69 & 0.52 & 0.67 & 3.29 & 2.09 \\
\hline
\end{tabular}

Figure 6.-Scaling from 91.4 to $35.6-\mathrm{cm}$-chord with $\mathrm{We}_{L}$ matched. NACA 0012 airfoils; $n_{0}, 0.5 ; V_{R}, 76 \mathrm{kt}$.

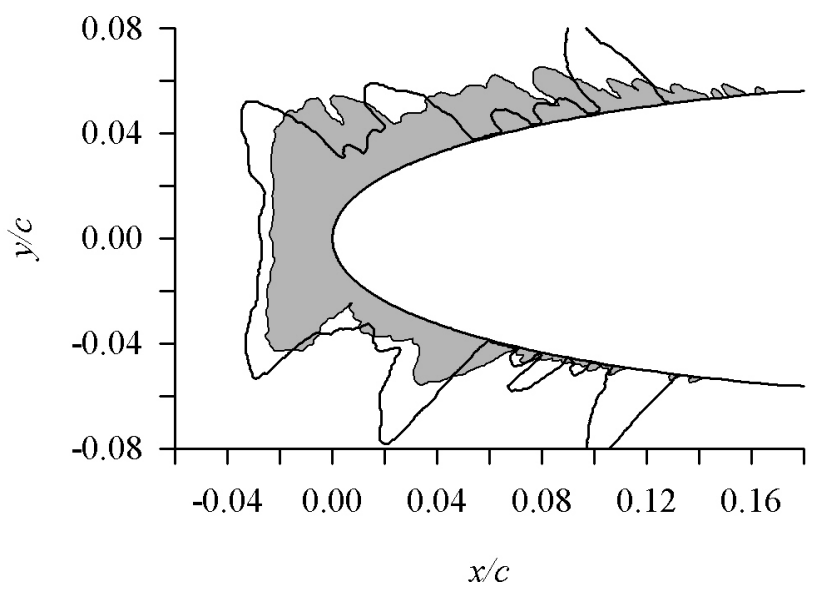

\begin{tabular}{|c|c|c|c|c|c|c|c|c|c|c|c|c|c|}
\hline & & & & & & $\Longrightarrow \mathrm{c}$ & $\begin{array}{l}=91.4 \mathrm{~cm} \\
=35.6 \mathrm{~cm}\end{array}$ & $\begin{array}{l}09-2 \\
09-3\end{array}$ & $\begin{array}{l}8 \text { Run } 4 \\
8 \text { Run } 9\end{array}$ & & & & \\
\hline Date/Run & $\begin{array}{l}c, \\
\mathrm{~cm}\end{array}$ & $\begin{array}{l}t_{t o t}, \\
{ }^{\circ} \mathrm{C}\end{array}$ & $\begin{array}{l}V, \\
\mathrm{kt}\end{array}$ & $\begin{array}{c}M V D, \\
\mu \mathrm{m}\end{array}$ & $\begin{array}{l}L W C, \\
\mathrm{~g} / \mathrm{m}^{3}\end{array}$ & $\begin{array}{c}\tau, \\
\min \end{array}$ & $\begin{array}{c}\beta_{0}, \\
\text { percent }\end{array}$ & $A_{c}$ & $\beta_{0} A_{c}$ & $n_{0}$ & $\begin{array}{c}\mathrm{We}_{L}, \\
10^{6}\end{array}$ & $\begin{array}{l}\mathrm{We}_{f}, \\
10^{-16}\end{array}$ & $\begin{array}{l}h / d, \\
10^{-9}\end{array}$ \\
\hline $09-26-08 / 04$ & 91.4 & -18.1 & 76 & 148 & 1.78 & 11.2 & 94.1 & 1.76 & 1.66 & 0.52 & 0.68 & 3.03 & 1.68 \\
\hline 09-30-08/09 & 35.6 & -10.4 & 141 & 66 & 1.18 & 4.00 & 94.3 & 1.99 & 1.88 & 0.48 & 0.91 & 4.37 & 1.97 \\
\hline
\end{tabular}

Figure 7.-Scaling from 91.4 to $35.6-\mathrm{cm}$-chord with $W_{\mathrm{f}}$ and $(h / d)$ matched. NACA 0012 airfoils; $n_{0}, 0.5 ; V_{R}, 76 \mathrm{kt}$. 
In Figure 6 the scale and reference values of $\beta_{0}, \beta_{0} A_{c}, n_{0}$ and $\mathrm{We}_{L}$ all matched within 2 percent, and the size and shape of the reference ice were well simulated by the scale test in the leading-edge region. However, the scale ice feathers showed relatively larger formations than recorded in the reference test. Further study to isolate these large-feather conditions is needed to improve scaling performance. In Figure 7 the scale and reference values of $\beta_{0}$ matched well but $A_{c}$ and $\beta_{0} A_{c}$ were just within 12 percent, $n_{0}$ was within 8 percent, $\mathrm{We}_{f}$ agreed only within about 31 percent and $h / d$ was within 15 percent. The large differences in matching $\mathrm{We}_{f}$ and $h / d$ occurred because the scale $L W C$ value was increased to 118 percent of the planned value (i.e., 1.18 instead of $1.00 \mathrm{~g} / \mathrm{m}^{3}$ ) while the reference $L W C$ value was reduced by 8 percent from its planned value (i.e., 1.78 instead of $1.94 \mathrm{~g} / \mathrm{m}^{3}$ ) based on the calibration data. The Olsen method was again applied to adjust the spray time and air temperature for scale test to keep $n_{0}$ and $\beta_{0} A_{c}$ close to the planned value. The shape of the reference ice was simulated fairly well by the scale test in the leading-edge region, but the size of the scale ice including the horns was bigger than the reference. In addition, many large ice feathers were observed for scale test in Figure 7.

For a higher reference velocity of $100 \mathrm{kt}$, similar ice shape comparisons were made with the 91.4-cm reference conditions scaled to $35.6 \mathrm{~cm}$, and the results were shown in Figures 8 and 9 . The reference $M V D$ was $195 \mu \mathrm{m}$ and the scale $M V D$ was about $87 \mu \mathrm{m}$. In both cases, the scale and reference values of $\beta_{0}, \beta_{0} A_{c}$, and $n_{0}$ matched within 3 percent. Reference and scale $\mathrm{We}_{L}$ in Figure 8 matched within about 2 percent, and the $\mathrm{We}_{f}$ and $h / d$ for Figure 9 agreed within 3 percent. In Figure 8 the scale ice shape was able to simulate the reference main ice shape and feather region well. In Figure 9, however, the scale test produced a smaller horn angle than the reference, although it had the correct horn size and reproduced well the feather size and density.

Given the repeatability variations encountered in the IRT for SLD conditions, it can be concluded that for SLD droplets in conditions where the droplet impact could interact strongly with the surface sheardriven film flow the constant $\left(\mathrm{We}_{L}\right.$ and $h / d$ ) method seems to be a better choice of similarity parameters for determining scale velocity and liquid water content than the constant $\left(\mathrm{We}_{f}\right.$ and $\left.h / d\right)$ method at stagnation point freezing fractions of 0.3 and 0.5. Additional tests at these freezing fractions are needed to better assess the constant $\left(\mathrm{We}_{L}\right.$ and $\left.h / d\right)$ method. The preliminary assessment is, however, that any of the two methods can produce acceptable scaling simulation for $n_{0}=0.3$ and 0.5 . If scale simulations are needed at such low freezing fractions, it is recommended that, due to the variability of shapes, tests be repeated with more than one test entry.

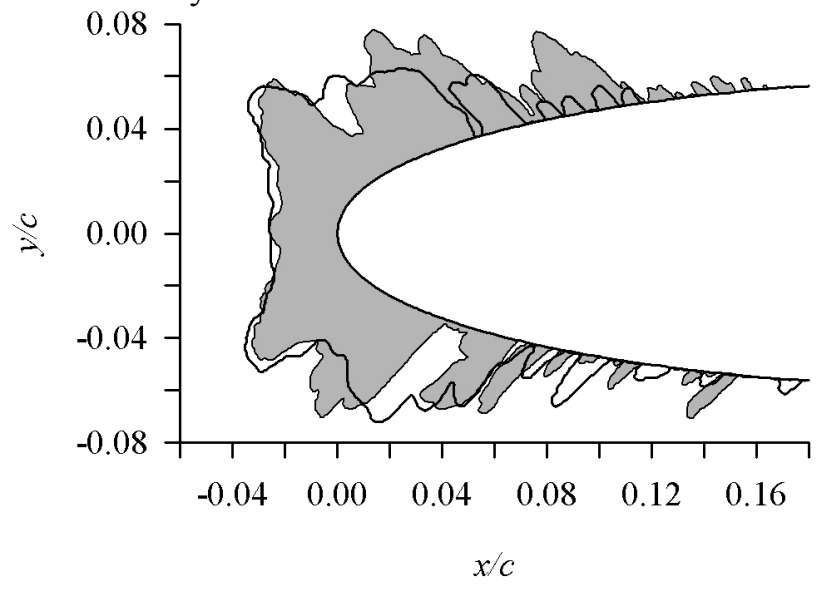

\begin{tabular}{|c|c|c|c|c|c|c|c|c|c|c|c|c|c|}
\hline \multirow[b]{2}{*}{ Date/Run } & \multirow[b]{2}{*}{$\begin{array}{l}c, \\
\mathrm{~cm}\end{array}$} & \multirow[b]{2}{*}{$\begin{array}{l}t_{t o t}, \\
{ }^{\circ} \mathrm{C}\end{array}$} & \multirow[b]{2}{*}{$\begin{array}{l}V, \\
\mathrm{kt}\end{array}$} & \multirow[b]{2}{*}{$\begin{array}{c}M V D, \\
\mu \mathrm{m}\end{array}$} & \multicolumn{5}{|c|}{$\begin{aligned} \mathrm{c}=91.4 \mathrm{~cm}, 09-26-08 \text { Run } 3 \\
\mathrm{c}=35.6 \mathrm{~cm}, 09-30-08 \text { Run } 5\end{aligned}$} & \multirow[b]{2}{*}{$n_{0}$} & \multirow[b]{2}{*}{$\begin{array}{c}\mathrm{We}_{L}, \\
10^{6} \\
\end{array}$} & \multirow[b]{2}{*}{$\begin{array}{l}\mathrm{We}_{f} \\
10^{-16}\end{array}$} & \multirow[b]{2}{*}{$\begin{array}{l}h / d, \\
10^{-9}\end{array}$} \\
\hline & & & & & $\begin{array}{l}L W C, \\
\mathrm{~g} / \mathrm{m}^{3}\end{array}$ & $\underset{\tau}{\tau}$ & $\begin{array}{c}\beta_{0}, \\
\text { percent }\end{array}$ & $A_{c}$ & $\beta_{0} A_{c}$ & & & & \\
\hline $09-26-08 / 03$ & 91.4 & -14.1 & 100 & 198 & 1.07 & 14.0 & 96.3 & 1.75 & 1.69 & 0.52 & 1.18 & 0.74 & 0.81 \\
\hline $09-30-08 / 05$ & 35.6 & -5.9 & 159 & 87 & 0.57 & 6.62 & 96.2 & 1.80 & 1.73 & 0.51 & 1.16 & 0.87 & 1.03 \\
\hline
\end{tabular}

Figure 8.-Scaling from 91.4 to $35.6-\mathrm{cm}$-chord with $W e_{L}$ matched. NACA 0012 airfoils; $n_{0}, 0.5 ; V_{R}, 100 \mathrm{kt}$. 


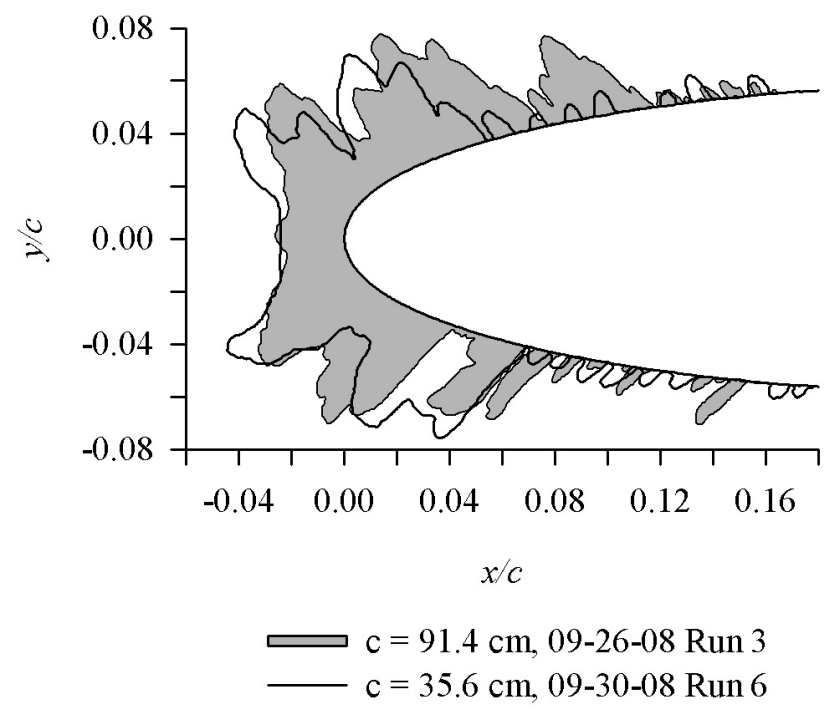

\begin{tabular}{|c|c|c|c|c|c|c|c|c|c|c|c|c|c|}
\hline Date/Run & $\begin{array}{c}c, \\
\mathrm{~cm}\end{array}$ & $\begin{array}{l}t_{t o t}, \\
{ }^{\circ} \mathrm{C}\end{array}$ & $\begin{array}{l}V, \\
\mathrm{kt}\end{array}$ & $\begin{array}{c}M V D, \\
\mu \mathrm{m}\end{array}$ & $\begin{array}{l}L W C, \\
\mathrm{~g} / \mathrm{m}^{3}\end{array}$ & $\begin{array}{c}\tau, \\
\min \end{array}$ & $\begin{array}{c}\beta_{0}, \\
\text { percent }\end{array}$ & $A_{c}$ & $\beta_{0} A_{c}$ & $n_{0}$ & $\begin{array}{c}\mathrm{We}_{L}, \\
10^{6}\end{array}$ & $\begin{array}{l}\mathrm{We}_{f}, \\
10^{-16}\end{array}$ & $\begin{array}{l}h / d, \\
10^{-9}\end{array}$ \\
\hline $09-26$ & 91.4 & -14.1 & 100 & 198 & 1.07 & 14.0 & 96.3 & 1.75 & 1.69 & 0.52 & 1.18 & 0.74 & 0.81 \\
\hline $09-30-08 / 06$ & 35.6 & -6.0 & 186 & 86 & 0.54 & 5.65 & 96.4 & 1.70 & 1.64 & 0.53 & 1.58 & 0.72 & 0.83 \\
\hline
\end{tabular}

Figure 9.-Scaling from 91.4 to $35.6-\mathrm{cm}$-chord with $W e_{f}$ and $(h / d)$ matched. NACA 0012 airfoils; $n_{0}, 0.5 ; V_{R}, 100 \mathrm{kt}$.

\section{Conclusion}

Icing scaling tests were performed in the NASA Glenn Icing Research Tunnel to evaluate a scaling method, developed and proposed by Feo for glaze icing conditions, in which the scale liquid water content and velocity were found by matching reference and scale values of the INTA nondimensional water-film thickness expression $h / d$ and the film Weber number $\mathrm{We}_{f}$. For comparison, tests were also performed using the constant $\mathrm{We}_{L}$ method. The reference tests used a full-span, fiberglass, 91.4-cm-chord NACA 0012 model with velocities of 76 and 100 knot and $M V D$ sizes of 150 and $195 \mu \mathrm{m}$. Scale-toreference model size ratio was 1:2.6. All tests were made at $0^{\circ} \mathrm{AOA}$. Results were presented for stagnation point freezing fractions of 0.3 and 0.5 .

For freezing fraction of 0.5 , all methods resulted in scale accretions closely matching the size of the reference, but somewhat better agreement with the reference horn angles was typically achieved with the constant $\left(\mathrm{We}_{L}\right.$ and $\left.h / d\right)$ method than with the constant $\left(\mathrm{We}_{f}\right.$ and $\left.h / d\right)$ method. At a freezing fraction of 0.3, the two methods were judged equal in providing simulations of the reference shape within the ice-shape repeatability. At low freezing fractions, poorer repeatability has been observed than for higher freezing fractions. Conclusions of this study regarding the constant- $\mathrm{We}_{L}$ and constant- $\mathrm{We}_{f}$ methods of finding scale velocity agreed with those of Reference 12 and, in which any scaling method considered for glaze ice accretion has to be consistent with the presumption that both Re and We are important parameters in describing those water-film phenomena that affect ice accretion.

\section{References}

1. Feo, A. and Tsao, J.C., "The Water Film Weber Number in Glaze Icing Scaling," SAE Aircraft \& Engine Icing International Conference, SAE-2007-01-3295, September 24-27, 2007.

2. Anderson, David N., "Manual of Scaling Methods," NASA/CR-2004-212875, March 2004.

3. Anderson, D.N and Tsao, J.C., "Ice Shape Scaling for Aircraft in SLD Conditions," NASA/CR2008-215302 and DOT/FAA/AR-07/55, September 2008. 
4. Bilanin, A.J., "Proposed Modifications to the Ice Accretion/Icing Scaling Theory," AIAA Paper AIAA-88-0203, January 1988.

5. Bilanin, Alan J. and Anderson, David N., "Ice Accretion With Varying Surface Tension," AIAA-950538 and NASA TM 106826, January 1995.

6. Kind, R.J., Dillon, T., Gaydos, J.A. and Oleskiw, M., "Evidence for the Importance of Scaling Viscous Effects in the Water Film in Glaze Icing Tests," AIAA-98-0196, January 1998.

7. Anderson, David N. and Ruff, Gary A., "Evaluation of Methods to Select Scale Velocities in Icing Scaling Tests," AIAA-99-0244, January 1999.

8. Anderson, David N., "Effect of Velocity in Icing Scaling Tests," AIAA-2000-0236, January 2000.

9. Mundo, C., Sommerfeld, M. and Tropea, C., "Droplet-Wall Collisions: Experimental Studies of the Deformation and Breakup Process," Int. J. Multiphase Flow, vol. 21, no. 2, 1995, pp. 151-173.

10. Feo, A. and Urdiales, M., "Stagnation Point Probe in a Water Spray Immersed in an Airstream," $\phi A E / T N O / 0452 / 003 / I N T A / 95$, Instituto Nacional de Técnica Aeroespacial, February 1995.

11. Feo, A., "Icing Scaling With Surface Film Thickness Similarity for High $L W C$ Conditions," AE/PRO/4420/184/INTA/00, Instituto Nacional de Técnica Aeroespacial, October 2000.

12. Anderson, David N. and Feo, Alejandro, "Ice-Accretion Scaling Using Water-Film Thickness Parameters," AIAA-2002-0522, January 2002.

13. Feo, A., "Similarity of Water Film Weber Number and Film Thickness in Icing Scaling," AE/TNO/4420/264/INTA/01, Instituto Nacional de Técnica Aeroespacial, October 2001.

14. Feo, A and Urdiales, M. Circular Cylinder Film Thickness Measurements Due to an Incident Water Spray. AE/TNO/4420/363/INTA/04. July 2004.

15. A. Experimental Similarity Results Using an Stagnation Point Probe for a Limited Number of SLD conditions. Presented at NASA/INTA Meeting on Icing Physics Research. Cleveland, Ohio. November 2005.

16. Ruff, G.A., "Analysis and Verification of the Icing Scaling Equations,” AEDC-TR-85-30, vol. 1 (rev), March 1986.

17. Langmuir, Irving and Blodgett, Katharine B. "A Mathematical Investigation of Water Droplet Trajectories,” Army Air Forces Technical Report No. 5418, February 1946.

18. Abbott, Ira H. and von Doenhoff, Albert E., Theory of Wing Sections, Dover, New York, 1959, pp. 114 and 321.

19. Messinger, B.L., "Equilibrium Temperature of an Unheated Icing Surface as a Function of Airspeed," J. Aeron. Sci., vol. 20 no. 1, January 1953, pp. 29-42.

20. Tribus, Myron, Young, G.B.W. and Boelter, L.M.K., "Analysis of Heat Transfer Over a Small Cylinder in Icing Conditions on Mount Washington," Trans. ASME, vol. 70, November 1948, pp. 971-976.

21. Charpin, Francois and Fasso, Guy, "Essais de givrage dans la grande soufflerie de Modane sur maquettes a echelle grandeur et echelle reduite," L'Aeronautique et l'Astronautique, no. 38, 1972, pp. 23-31. English translation published as "Icing Testing in the Large Modane Wind-Tunnel on Full-Scale and Reduced Scale Models," NASA TM-75373, March 1979.

22. Anderson, David N. and Tsao, J.C., "Additional Results of Ice-Accretion Scaling at SLD Conditions," AIAA-2003-0390, January 2003 and NASA/CR-2005-213850, August 2005.

23. Bartlett, C. Scott, "An Analytical Study of Icing Similitude for Aircraft Engine Testing," DOT/FAA/CT-86/35 and AEDC-TR-86-26, October 1986.

24. Bartlett, C. Scott, "Icing Scaling Considerations for Aircraft Engine Testing," AIAA-88-0202, January 1988.

25. Oleskiw, Myron M., De Gregorio, Fabrizio and Esposito, Biagio, "The Effect of Altitude on Icing Tunnel Airfoil Icing Simulation," Proceedings of the FAA International Conference on Aircraft Inflight Icing, DOT/FAA/AR-96/81, II, August 1996, pp. 511-520.

26. Ide, Robert F. and Oldenburg, John R., "Icing Cloud Calibration of the NASA Glenn Icing Research Tunnel," AIAA-2001-0234, January 2001.

27. SigmaScan Pro, image-processing software, ver. 5.0, Systat Software, Inc., Point Richmond, CA. 


\begin{tabular}{|c|c|c|c|c|c|}
\hline \multicolumn{5}{|c|}{ REPORT DOCUMENTATION PAGE } & $\begin{array}{l}\text { Form Approved } \\
\text { OMB No. 0704-0188 }\end{array}$ \\
\hline \multicolumn{6}{|c|}{$\begin{array}{l}\text { The public reporting burden for this collection of information is estimated to average } 1 \text { hour per response, including the time for reviewing instructions, searching existing data sources, gathering and maintaining the } \\
\text { data needed, and completing and revieving the collection of information. Send comments regarding this burden estimate or any other aspect of this collection of information, including suggestions for reducing this } \\
\text { burden, to Department of Defense, Washington Headquarters Services, Directorate for Information Operations and Reports (07004-0188), } 1215 \text { Jefferson Davis Highway, Suite } 1204 \text {, Arlington, VA } 22202-4302 \text {. } \\
\text { Respondents should be aware that notwithstanding any other provision of law, no person shall be subject to any penalty for failing to comply with a collection of information if it does not display a currently valid OMB } \\
\text { control number. } \\
\text { PLEASE DO NOT RETURN YOUR FORM TO THE ABOVE ADDRESS. }\end{array}$} \\
\hline \multicolumn{2}{|c|}{$\begin{array}{l}\text { 1. REPORT DATE (DD-MM-YYYY) } \\
01-03-2010\end{array}$} & \multicolumn{3}{|c|}{$\begin{array}{l}\text { 2. REPORT TYPE } \\
\text { Technical Memorandum }\end{array}$} & 3. DATES COVERED (From - To) \\
\hline \multirow{3}{*}{\multicolumn{5}{|c|}{$\begin{array}{l}\text { 4. TITLE AND SUBTITLE } \\
\text { Evaluation of the Water Film Weber Number in Glaze Icing Scaling }\end{array}$}} & 5a. CONTRACT NUMBER \\
\hline & & & & & 5b. GRANT NUMBER \\
\hline & & & & & 5c. PROGRAM ELEMENT NUMBER \\
\hline \multirow{3}{*}{\multicolumn{5}{|c|}{$\begin{array}{l}\text { 6. AUTHOR(S) } \\
\text { Tsao, Jen-Ching; Kreeger, Richard, E.; Feo, Alejandro }\end{array}$}} & 5d. PROJECT NUMBER \\
\hline & & & & & 5e. TASK NUMBER \\
\hline & & & & & $\begin{array}{l}\text { 5f. WORK UNIT NUMBER } \\
\text { WBS } 457280.02 .07 .03 .03 .04\end{array}$ \\
\hline \multicolumn{5}{|c|}{$\begin{array}{l}\text { 7. PERFORMING ORGANIZATION NAME(S) AND ADDRESS(ES) } \\
\text { National Aeronautics and Space Administration } \\
\text { John H. Glenn Research Center at Lewis Field } \\
\text { Cleveland, Ohio 44135-3191 }\end{array}$} & $\begin{array}{l}\text { 8. PERFORMING ORGANIZATION } \\
\text { REPORT NUMBER } \\
\text { E-17153 }\end{array}$ \\
\hline \multirow{2}{*}{\multicolumn{5}{|c|}{$\begin{array}{l}\text { 9. SPONSORING/MONITORING AGENCY NAME(S) AND ADDRESS(ES) } \\
\text { National Aeronautics and Space Administration } \\
\text { Washington, DC 20546-0001 }\end{array}$}} & $\begin{array}{l}\text { 10. SPONSORING/MONITOR'S } \\
\text { ACRONYM(S) } \\
\text { NASA }\end{array}$ \\
\hline & & & & & $\begin{array}{l}\text { 11. SPONSORING/MONITORING } \\
\text { REPORT NUMBER } \\
\text { NASA/TM-2010-216101 }\end{array}$ \\
\hline \multicolumn{6}{|c|}{$\begin{array}{l}\text { 12. DISTRIBUTION/AVAILABILITY STATEMENT } \\
\text { Unclassified-Unlimited } \\
\text { Subject Category: } 03 \\
\text { Available electronically at http://gltrs.grc.nasa.gov } \\
\text { This publication is available from the NASA Center for AeroSpace Information, 443-757-5802 }\end{array}$} \\
\hline \multicolumn{6}{|c|}{ 13. SUPPLEMENTARY NOTES } \\
\hline \multirow{2}{*}{\multicolumn{6}{|c|}{$\begin{array}{l}\text { 14. ABSTRACT } \\
\text { Icing scaling tests were performed in the NASA Glenn Icing Research Tunnel to evaluate a new scaling method, developed and proposed by } \\
\text { Feo for glaze icing, in which the scale liquid water content and velocity were found by matching reference and scale values of the } \\
\text { nondimensional water-film thickness expression and the film Weber number. For comparison purpose, tests were also conducted using the } \\
\text { constant } \mathrm{We}_{L} \text { method for velocity scaling. The reference tests used a full-span, fiberglass, } 91.4-\mathrm{cm} \text {-chord NACA } 0012 \text { model with velocities } \\
\text { of } 76 \text { and } 100 \text { knot and } M V D \text { sizes of } 150 \text { and } 195 \mu \mathrm{m} \text {. Scale-to-reference model size ratio was } 1: 2.6 \text {. All tests were made at } 0^{\circ} \text { AOA. } \\
\text { Results will be presented for stagnation point freezing fractions of } 0.3 \text { and } 0.5 \text {. } \\
\text { 15. SUBJECT TERMS } \\
\text { Icing; Scaling; Water film; Weber number; Glaze }\end{array}$}} \\
\hline & & & & & \\
\hline \multicolumn{3}{|c|}{ 16. SECURITY CLASSIFICATION OF: } & $\begin{array}{l}\text { 17. LIMITATION OF } \\
\text { ABSTRACT }\end{array}$ & $\begin{array}{l}\text { 18. NUMBER } \\
\text { OF }\end{array}$ & $\begin{array}{l}\text { 19a. NAME OF RESPONSIBLE PERSON } \\
\text { STI Help Desk (email:help@sti.nasa.gov) }\end{array}$ \\
\hline $\begin{array}{l}\text { a. REPORT } \\
\text { U }\end{array}$ & $\begin{array}{l}\text { b. ABSTRACT } \\
\text { U }\end{array}$ & \begin{tabular}{|l|} 
c. THIS \\
PAGE \\
U \\
\end{tabular} & UU & $\begin{array}{l}\text { PAGES } \\
20\end{array}$ & $\begin{array}{l}\text { 19b. TELEPHONE NUMBER (include area code) } \\
443-757-5802\end{array}$ \\
\hline
\end{tabular}



